\title{
Pengaruh pewarna alami kulit buah naga merah (Hylocereus polyrhizus (F.A.C. Weber) Briton \& Rose) terhadap aktivitas antioksidan nata de coco
}

\section{Hilyatuz Zahro ${ }^{1 *}$, Novi Febrianti ${ }^{2}$}

Pendidikan Biologi, Fakultas Keguruan dan Ilmu Pendidikan, Universitas Ahmad Dahlan

Jl. Jendral Ahmad Yani (Ringroad Selatan) Tamanan, Banguntapan, Bantul

Daerah Istimewa Yogyakarta 55191

1 hilyatuzzahro41@gmail.com *; 2 novifebrianti@pbio.uad.ac.id

*korespondensi penulis

\begin{abstract}
Abstrak
Kulit buah naga merah yang kurang dimanfaatkan dengan baik sehingga menjadikannya sebagai limbah yang dapat mencemari lingkungan. Kulit buah naga merah sangat potensial dijadikan sebagai pewarna alami yang memiliki aktivitas antioksidan yang tinggi. Tujuan dari penelitian ini adalah untuk mengetahui aktivitas antioksidan dan kadar flavonoid pada nata de coco yang diberikan pewarna filtrat kulit buah naga merah. Penelitian dilakukan dengan menggunakan RAL (Rancangan Acak Lengkap) dengan 3 ulangan pada filtrat kulit buah naga merah sebagai pewarna alami pada nata de coco dengan 4 perlakuan $(0 \%, 25 \%, 50 \%$ dan 100\%). Aktivitas antioksidan yang diuji dengan mengukur nilai penghambatan sampel terhadap radikal bebas DPPH (1,1-difenil, 2-pikrilhidrazil) dan kadar flavonoid diuji secara spektrofotometri Visible. Data diolah dengan analisis varian (One Way Annova) dan dilanjutkan uji LSD. Hasil penelitian menunjukkan bahwa aktivitas antioksidan tertinggi pada perlakuan $\mathrm{C}$ dengan konsentrasi 50\% sebesar 10,32\%, sedangkan kadar flavonoid tertinggi pada perlakuan D dengan konsentrasi $100 \%$ sebesar $83,06 \mu \mathrm{g} / \mathrm{g}$. Kadar flavonoid dengan aktivitas antioksidan menunjukkan adanya hubungan yang positif.
\end{abstract}

Kata kunci: kulit buah naga merah, nata de coco, aktivitas antioksidan, flavonoid

\begin{abstract}
The skin of the red dragon fruit is underutilized so that it makes it a waste that can pollute the environment. Red dragon fruit skin is very potential to be used as a natural coloring which has high antioxidant activity. The purpose of this study was to determine the antioxidant activity and levels of flavonoids on nata de coco which were given red dragon fruit skin filtrate dyes. The study was conducted using RAL (Completely Randomized Design) with 3 replications on the red dragon fruit skin filtrate as a natural dye on nata de coco with 4 treatments $(0 \%, 25 \%, 50 \%$ and $100 \%)$. Antioxidant activity was tested by measuring the inhibitory value of the sample against DPPH free radicals (1,1-diphenyl, 2-picrylhydrazyl) and flavonoid levels were tested by Visible spectrophotometry. Data were processed by analysis of variance (One Way Annova) and continued by LSD test. The results showed that the highest antioxidant activity in treatment $\mathrm{C}$ with a concentration of $50 \%$ was $10.32 \%$, while the highest flavonoid levels in treatment D with a concentration of $100 \%$ was $83.06 \mu \mathrm{g} /$ g. Flavonoid levels with antioxidant activity show a positive relationship.
\end{abstract}

Keywords: red dragon fruit peels, nata de coco, antioxidant activity, flavonoids 


\section{PENDAHULUAN}

Indonesia merupakan negara beriklim tropis yang memiliki keanekaragaman tanaman yang tinggi, salah satunya tanaman buah naga. Buah naga mulai populer sejak tahun 2000 di Indonesia, dalam satu hektar tanaman buah naga akan menghasilkan sekitar 6-7 ton buah naga sekali musim panen bahkan dapat mencapai lebih dari 50 ton per tahun (Kristanto, 2008). Salah satu jenis tanaman buah naga yang berhasil dibudidayakan di Indonesia adalah buah naga daging merah dengan nama ilmiah Hylocereus polyrhizus (Van stenis, 1975). Sebagian besar masyarakat memanfaatkan buah naga merah hanya bagian daging buahnya, sedangkan kulitnya kurang dimanfaatkan dengan baik sehingga menjadikannya sebagai limbah yang dapat mencemari lingkungan.

Kulit buah naga merah sangat potensial untuk dikembangkan, karena mengandung senyawa betasianin yang termasuk ke dalam golongan betalain sebagai pewarna alami dan mengandung aktivitas antioksidan yang tinggi (Khalida, 2010). Betasianin adalah pigmen tumbuhan yang memberikan warna merah keunguan pada bagian daun dan buah. Sifat dari betasianin adalah larut air, mengandung nitrogen, dan sintesanya ditingkatkan oleh cahaya (Cai dkk., 2005). Berdasarkan penelitian yang dilakukan Wu dkk. (2006) bahwa pada kulit buah naga kering/100 g mengandung betasianin sebesar $13.8 \pm 0.85 \mathrm{mg}$. Senyawa yang bertanggung jawab terhadap aktivitas antioksidan, yaitu tanin (Zhang dkk., 2009), dan komponen fenolik seperti diterpen fenolik, asam fenolik, dan flavonoid (Javanmardi dkk., 2003).

Flavonoid mempunyai aktivitas antioksidan yang kuat yang merupakan pendonor hidrogen yang sangat baik. Flavonoid mempunyai aktivitas antioksidan lebih baik daripada vitamin C (asam askorbat), vitamin $\mathrm{E}$ (tokoferol) yang merupakan antioksidan mayor dalam tubuh (Prakash dan Gupta, 2009). Antioksidan adalah senyawa kimia yang dapat menyumbangkan satu atau lebih elektron kepada radikal bebas, sehingga reaksi radikal bebas tersebut dapat terhambat dan mencegah terbentuknya radikal bebas baru (Winarsi, 2007). Senyawa flavonoid sebagai antioksidan pada masa sekarang ini sangat banyak diteliti, karena senyawa flavonoid yang terdapat pada antioksidan memiliki kemampuan untuk merubah atau mereduksi resiko yang dapat ditimbulkan oleh radikal bebas dan juga dapat dimanfaatkan sebagai anti-radikal bebas (Handayani dan Sulistyo, 2008). Radikal bebas adalah molekul tidak stabil yang memiliki elektron tidak berpasangan pada orbital luarnya sehingga bersifat sangat reaktif. Radikal bebas dalam jumlah kecil digunakan pada respon seluler dan sistem 
imun, namun pada konsentrasi yang tinggi radikal bebas dapat menghasilkan stres oksidatif yang menyebabkan kerusakan struktur sel, termasuk kerusakan lipid, protein dan DNA (Winarsi, 2007).

Selain sebagai sumber antioksidan, kulit buah naga merah juga dapat dimanfaatkan sebagai pewarna alami pengganti pewarna sintetik yang dapat diaplikasikan dalam pembuatan produk makanan, seperti nata de coco. Jika ditinjau dari aspek kesehatan, penambahan pewarna alami lebih aman dibandingkan dengan pewarna sintetik. Pembuatan pewarna sintetik ini biasanya melalui perlakuan pemberian asam sulfat atau asam nitrat yang seringkali terkontaminasi oleh arsen atau logam berat lain yang bersifat racun bagi tubuh (Winarno, 2002). Pewarna alami pada kulit buah naga merah digunakan sebagai pengganti pewarna sintetik.

Nata de coco merupakan produk pangan berbahan dasar air kelapa. Kata nata digunakan untuk menyebut pertumbuhan menyerupai gel atau agar-agar yang terapung yang dihasilkan oleh bakteri Acetobacter xylinum di permukaan media yang mengandung sumber karbon (gula), hidrogen, nitrogen, dan asam (Hamad dkk., 2011). Pembuatan nata mengandalkan proses fermentasi yang dilakukan oleh bakteri Acetobacter xylinum terhadap starter yang dalam hal ini adalah air kelapa.

\section{PEMBAHASAN}

\section{Aktivitas Antioksidan}

Penentuan aktivitas antioksidan dilakukan dengan menggunakan metode DPPH $(1,1$ difenil-2-pikrihirdazil) secara spektrofotometri visible. Aktivitas antioksidan dinyatakan dalam persen penghambatan radikal bebas yang didapatkan dari perbandingan selisih absorbansi blanko dengan sampel terhadap absorbansi larutan blanko. Hasil dari aktivitas antioksidan yang dinyatakan dalam persen penghambatan radikal bebas disajikan pada Tabel 1.

Tabel 1. Nilai aktivitas antioksidan

\begin{tabular}{cccccc}
\hline \multirow{2}{*}{ No } & Perlakua & \multicolumn{3}{c}{ Pengulangan } & \multirow{2}{*}{ Rata-Rata (\%) } \\
\cline { 3 - 5 } & $\mathbf{n}$ & $\mathbf{I}$ & $\mathbf{I}$ & III & \\
\hline 1. & $\mathrm{~A}$ & 0,94 & 1,77 & 1,88 & $1,53 \pm 0,51391$ \\
2. & $\mathrm{~B}$ & 7,19 & 7,51 & 7,93 & $7,54 \pm 0,37112$ \\
3. & $\mathrm{C}$ & 10,01 & 10,32 & 10,64 & $10,32 \pm 0,31501$ \\
4. & $\mathrm{D}$ & 10,22 & 10,43 & 10,11 & $10,25 \pm 0,16258$ \\
\hline
\end{tabular}

Berdasarkan Tabel 1, diagram perbandingan nilai aktivitas antioksidan dapat dilihat pada Gambar 1. 


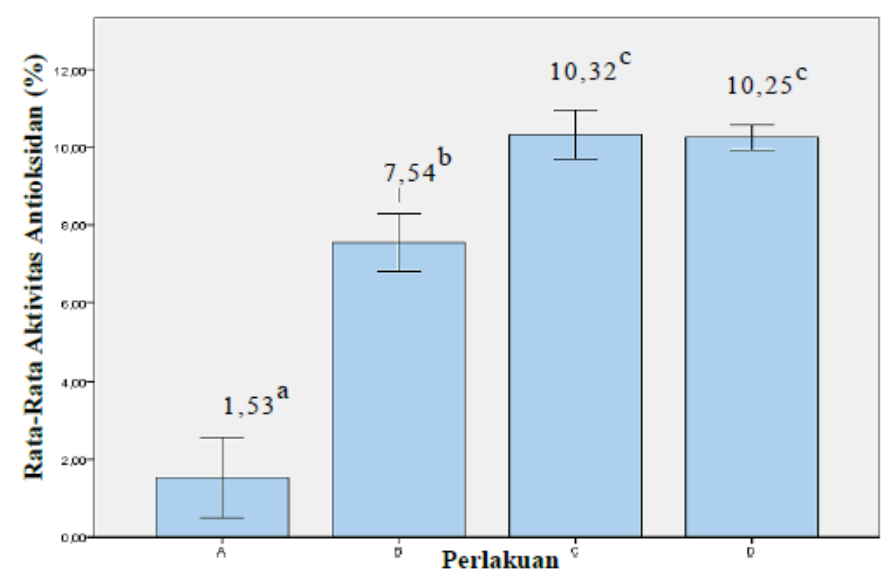

Gambar 1. Diagram perbandingan aktivitas antioksidan nata de coco

Berdasarkan Gambar 1. menunjukkan adanya perbedaan aktivitas antioksidan antara perlakuan pemberian pewarna filtrat kulit buah naga merah dengan tanpa pemberian pewarna filtrat kulit buah naga merah pada nata de coco. Aktivitas antioksidan tertinggi pada perlakuan dengan pemberian pewarna filtrat kulit buah naga merah pada nata de coco, yaitu perlakuan C dengan konsentrasi 50\% sebesar 10,32\%, sedangkan perlakuan terendah pada perlakuan B sebesar 7,54\%. Menurut Widianingsih (2016) bahwa peningkatan konsentrasi ekstrak berbanding lurus dengan persentase inhibisi (penghambatan). Hal ini juga mengacu pada prinsip kerja dari spektrofotometri, yaitu apabila radiasi atau cahaya putih dilewatkan melalui larutan berwarna, maka radiasi dengan panjang gelombang tertentu akan diserap (absorbsi) secara selektif dan radiasi lainnya akan diteruskan (transmisi). Absorbansi adalah perbandingan intensitas sinar yang diserap dengan intensitas sinar datang. Nilai absorbansi ini akan bergantung pada kadar zat yang terkandung di dalamnya, semakin banyak kadar zat yang terkandung dalam suatu sampel maka semakin banyak molekul yang akan menyerap cahaya pada panjang gelombang tertentu sehingga nilai absorbansi semakin besar atau dengan kata lain nilai absorbansi akan berbanding lurus dengan konsentrasi zat yang terkandung di dalam suatu sampel (Neldawati dkk., 2013). Pada penelitian ini diperoleh hasil bahwa perlakuan C dengan konsentrasi 50\% menghasilkan aktivitas antioksidan sedikit lebih tinggi dengan perbedaan yang tidak signifikan dibandingkan perlakuan D konsentrasi $100 \%$. Nata de coco pada perlakuan B, C, dan D memiliki aktivitas antioksidan yang tinggi dibandingkan dengan perlakuan A. Hal ini dapat dipengaruhi oleh kandungan flavonoid yang dihasilkan pada perlakuan tersebut juga tinggi. Menurut Rezaeizadeh (2011) flavonoid bertindak sebagai antioksidan dikarenakan memiliki gugus hidroksil yang dapat mendonorkan atom hidrogen kepada senyawa radikal bebas dan menstabilkan senyawa 
oksigen reaktif (ROS) serta memiliki gugus keton hidroksil yang dapat bertindak sebagai pengkelat logam yang menjadi katalis pada peroksidasi lipid.

Kulit buah naga merah yang digunakan sebagai pewarna alami nata de coco pada penelitian ini memiliki aktivitas antioksidan yang tinggi dibandingkan dengan kulit buah tanpa digunakan sebagai pewarna pada produk makanan, hal ini dibuktikan oleh penelitian yang dilakukan oleh Nurliyana, dkk (2010) bahwa dalam $1 \mathrm{mg} / \mathrm{mL}$ kulit buah naga merah mampu menghambat $83,48 \pm 1,02 \%$ radikal bebas sedangkan pada penelitian ini diperoleh hasil dalam $1 \mathrm{gr} / \mathrm{mL}$ sebesar $10,32 \%$.

Perlakuan A dengan konsentrasi 0\%, yaitu tidak diberikan pewarna filtrat kulit buah naga merah tetapi nata de coconya mempunyai aktivitas antioksidan. Hal ini dapat disebabkan dari proses fermentansi pada saat pembuatan nata de coco tersebut. Selama proses fermentasi nata, bakteri Acetobacter xylinum pada starter melakukan metabolisme terhadap sukrosa atau gula yang terdapat dalam media nata dan menghasilkan sejumlah asam-asam organik (Jasman dan Widianto, 2012). Produk asam organik yang dihasilkan oleh bakteri A. xylinum adalah asam asetat. Menurut Primurdia dan Kusnadi (2014) asam organik dapat menaikkan dan menstabilkan aktivitas antioksidan dengan melepaskan ion $\mathrm{H}^{+}$untuk mengikat radikal bebas dalam hal ini adalah DPPH.

\section{Kadar Flavonoid}

Penentuan kadar flavonoid total, dilakukan dengan menggunakan larutan standar kuersetin dibuat menjadi 8 deret konsentrasi, yaitu $0 ; 1,563 ; 3,125 ; 6,250 ; 12,5 ; 25 ; 50$ dan $100 \mu \mathrm{g} / \mathrm{mL}$. Pembuatan kurva baku larutan standar kuersetin dilakukan untuk mengetahui hubungan antara konsentrasi $(\mu \mathrm{g} / \mathrm{mL})$ dengan absorbansi. Hasil pengukuran dapat dilihat pada Tabel 2.

Tabel 2. Tabel absorbansi larutan standar kuersetin pada beberapa konsentrasi

\begin{tabular}{cc}
\hline Konsentrasi $(\boldsymbol{\mu g} / \mathbf{m L})$ & Absorbansi \\
\hline 0 & 0,000 \\
1,563 & 0,006 \\
3,125 & 0,017 \\
6,250 & 0,034 \\
12,5 & 0,063 \\
25 & 0,123 \\
50 & 0,228 \\
100 & 0,467 \\
\hline
\end{tabular}

Berdasarkan Tabel 8 dapat dibuat hubungan antara larutan standar kuersetin $(\mu \mathrm{g} / \mathrm{mL})$ dengan absorbansi, serta dicari persamaan regresi linier dan diperoleh persamaan $\mathrm{y}=$ $0,00463704 \mathrm{x}+0,00215730$, dengan $\mathrm{r}$ hitung $=0,99945$ dengan $\mathrm{x}=$ konsentrasi $(\mu \mathrm{g} / \mathrm{mL})$, dan 
$\mathrm{y}=$ absorbansi/nilai serapan. Dari persamaan linier diperoleh $\mathrm{R}^{2}$ 0,99945 yang berarti terdapat hubungan antara konsentrasi larutan standar kuersetin dengan absorbansi/nilai serapan.

Penetapan kadar flavonoid dalam sampel dihitung dengan mensubstitusikan absorbansi/nilai serapan larutan standar kuersetin kedalam variabel y dengan persamaan linier $y=0,00463704 x+0,00215730$. Data kadar total flavonoid tersaji pada Tabel 3.

Tabel 3. Tabel kadar flavonoid nata de coco

\begin{tabular}{ccccc}
\hline \multirow{2}{*}{ No } & \multirow{2}{*}{ Perlakuan } & \multicolumn{2}{c}{ Pengulangan } & \multirow{2}{*}{ Rata-rata $(\boldsymbol{\mu g} / \mathbf{g})$} \\
\cline { 3 - 4 } & & I & II & \\
\hline 1. & $\mathrm{~A}$ & 5,00 & 4,21 & $4,61 \pm 0,55861$ \\
2. & $\mathrm{~B}$ & 30,44 & 30,47 & $30,44 \pm 0,02121$ \\
3. & $\mathrm{C}$ & 38,56 & 38,59 & $38,61 \pm 0,02121$ \\
4. & $\mathrm{D}$ & 80,50 & 85,74 & $83,06 \pm 3,70524$ \\
\hline
\end{tabular}

Berdasarkan Tabel 3. Kadar Flavonoid nata de coco, diagram perbandingan nilai aktivitas antioksidan dapat dilihat pada Gambar 2.

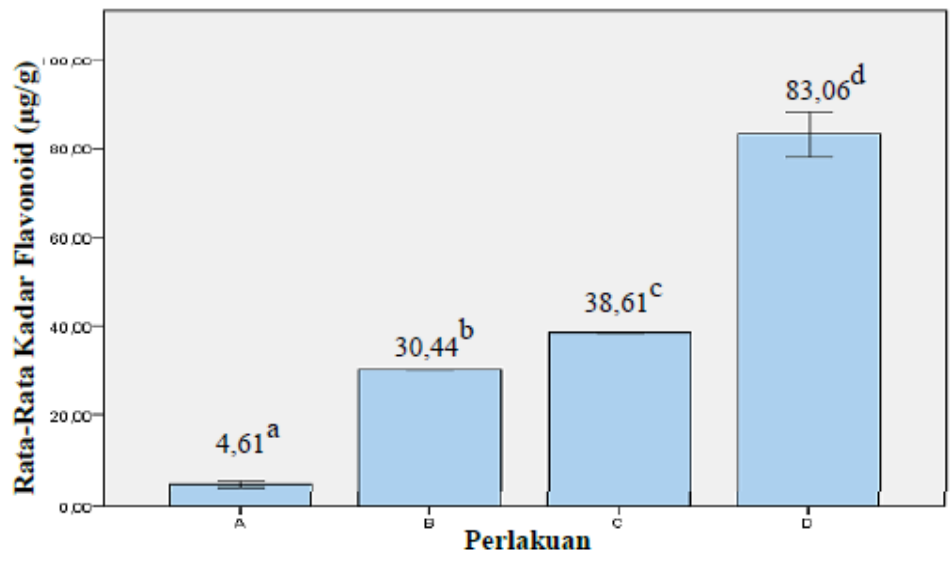

Gambar 2. Diagram perbandingan kadar flavonoid nata de coco

Berdasarkan data yang diperoleh pada Gambar 6. yang menunjukkan perbedaan rerata kadar flavonoid yang signifikan pada setiap perlakuan $(\mathrm{p}<0,005)$. Perlakuan D dengan konsentrasi 100\% menghasilkan kadar flavonoid yaitu sebesar 83,06 $\mu \mathrm{g} / \mathrm{g}$ lebih tinggi dari perlakuan B dengan konsentrasi 25\% sebesar 30,47 $\mu \mathrm{g} / \mathrm{g}$. Perbedaan kadar tersebut disebabkan oleh pemberian perlakuan pada filtrat kulit buah naga merah dengan konsentrasi yang berbeda. Senyawa flavonoid yang merupakan golongan dari polifenol tidak stabil terhadap perubahan pengaruh oksidasi, cahaya, dan perubahan kimia, sehingga apabila teroksidasi strukturnya akan berubah dan fungsinya sebagai bahan aktif akan menurun atau bahkan hilang (Handayani dan Sulistyo, 2008).

Filtrat kulit buah naga merah yang digunakan pada penelitian ini sebagai pewarna pada nata de coco yang menghasilkan kadar flavonoid lebih rendah dibandingkan penelitian yang 
dilakukan oleh Febrianti dkk. (2019) menggunakan kulit buah naga merah murni dan menghasilkan kadar flavonoid sebesar $0,1558 \mathrm{~g} / \mathrm{g}$. Perbedaan kadar flavonoid tersebut dapat diasumsikan bahwa pada penelitian ini, kulit buah naga merah digunakan sebagai pewarna nata de coco sehingga dalam menentukan kadar flavonoid tersebut jumlah filtrat kulit buah naganya tidak sebanyak penelitian yang dilakukan oleh Febrianti dkk.

\section{Hubungan antara kadar flavonoid dengan aktivitas antioksidan}

Pada umumnya kadar flavonoid akan memiliki hubungan yang positif dengan aktivitas antioksidan, artinya jika kandungan flavonoid tinggi maka aktivitas antioksidannya juga akan tinggi. Hasil yang diperoleh pada penelitian ini seperti pada Tabel 4.

\begin{tabular}{ccc}
$\begin{array}{c}\text { Tabel 4. Kadar flavonoid dan aktivitas antioksidan nata de coco } \\
\text { Perlakuan }\end{array}$ & $\begin{array}{c}\text { Kadar flavonoid } \\
(\boldsymbol{\mu} \mathbf{g} / \mathbf{g})\end{array}$ & $\begin{array}{c}\text { Aktivitas } \\
\text { antioksidan } \\
(\%)\end{array}$ \\
\hline A & 4,61 & 1,53 \\
B & 30,44 & 7,54 \\
C & 38,61 & 10,32 \\
D & 83,06 & 10,25 \\
\hline
\end{tabular}

Hubungan antara kadar flavonoid (x) dengan aktivitas antioksidan (y) mempunyai koefisien korelasi $r 2=0,6466$ dari persamaan korelasi $y=0,1017 x+3,4262$. Data dianalisis dengan uji nonparametric correlation yang menunjukkan nilai Sig. 0,002<0,05 sehingga H0 ditolak yang artinya data kadar flavonoid memiliki hubungan dengan aktivitas antioksidan.

Nilai koefisien korelasi yang dihasilkan dari persamaan korelasi tersebut menunjukkan adanya hubungan (korelasi) positif antara kadar flavonoid dengan aktivitas antioksidan karena nilai $\mathrm{r}$ tersebut mendekati satu $(\mathrm{r} \leq 1)$ dan dibuktikan dengan hasil analisis yang menunjukkan $\mathrm{p}<0,005$. Menurut Hasan (1999) korelasi positif adalah korelasi dari dua variabel, yaitu apabila variabel yang satu $(\mathrm{X})$ meningkat maka variabel yang lainnya $(\mathrm{Y})$ cenderung meningkat pula. Pada penelitian ini antara kadar flavonoid (X) meningkat dan aktivitas antioksidannya (Y) juga meningkat walaupun pada data perlakuan D berbeda tidak signifikan dengan data perlakuan $\mathrm{C}$.

\section{SIMPULAN}

Berdasarkan hasil penelitian tentang pengaruh pewarna kulit buah naga merah (Hylocereus polyrhizus (F.A.C, Weber) Britton \& Rose) terhadap aktivitas antioksidan nata de coco, yaitu: Konsentrasi filtrat kulit buah naga merah sebagai pewarna alami nata de coco yang menghasilkan aktivitas antioksidan tertinggi adalah konsentrasi 50\%, dan yang 
menghasilkan kadar flavonoid tertinggi adalah konsentrasi 100\%. Sedangkan saran yang diberikan dari penelitian ini, yaitu: perlu dilakukannya penelitian lebih lanjut dengan menggunakan daging buah naga merah sebagai pewarna nata de coco untuk mengetahui aktivitas antioksidan.

\section{REFERENSI}

Cai, Y.Z., Sun M \& Corke H. 2005. Characterization and Application of Betalain Pigment From Plants of Amaranthaceae. Trends in Food Science and Technology. 16: 370376.

Febrianti, Novi., Sofia Mubarika Haryana., Purwanti Pratiwi Purbosari., Triana Hertiani \& Sukarti Moeljopawiro. 2019. Antioxidant Potency of Red Dragon Fruit Flesh and Peel Prepared by Different Methods. Current Nutrition and Food Science. Unpublished.

Hamad, Alwaani., Nur Afifah Andriyani., Haryo Wibisono \& Heru Sutopo. 2011. Pengaruh Penambahan Sumber Karbon Terhadap Kondisi Fisik Nata de coco. Techno. 12 (2).

Handayani, Rini \& Joko Sulistyo. 2008. Sintesis Senyawa Flavonoid- $\alpha$-Glikosida secara Reaksi Transglikosilasi Enzimatik dan Aktivitasnya sebagai Antioksidan. Biodiversitas. 0 (1): 1-4.

Hasan, Iqbal. 1999. Pokok-Pokok Materi STATISTIKA 2 (Statistik Inferensif). Jakarta: Bumi Aksara.

Javanmardi J., Stushnoff C., Locke E \& Vivanco J.M. 2003. Antioxidant activity and total phenolic content of Iranian Ocimum accessions. Food Chemistry. 85: 547-550.

Khalida Y, 2010. A comparative study on the extraction of betacyanin in the peel and flesh of dragon fruit. Malasyia: Faculty of Chemical and Natural Resources Engineering Universiti Malasyia Pahang.

Kristanto. 2008. Buah Naga Pembudidayaan di Pot dan di Kebun. Jakarta: Penebar Swadaya.

Neldawati., Ratnawulan \& Gusnedi. 2013. Analisis Nilai Absorbansi dalam Penentuan Kadar Flavonoid untuk Berbagai Jenis Daun Tanaman Obat. Universitas Negeri Padang: Jurnal Fakultas Teknik, Matematika dan IPA.

Nurliyana, R., S. Zahir., M. Sulaeman., M. R. Aisyah \& Rahim, K. 2010. Antioxidant Study of Pulps and Peels of Dragon Fruit: A Comparative Study. International Food Research Journal. 17: 367-375.

Prakash., Fred Rigelhof \& Eugene MIller. 2001. Antioxidant Activity. Medallion LaboratoryAnalytical Progress. 19:2.

Rezaeizadeh, A Zuki ABZ., M Abdollahi., Goh YM., Noordin MM \& Hamid M Azmi TI. 2011. Determination Of Antioxidant Activity In Methanolic And Chloroformic Extract Of Momordica Charantia. African Journal of Biotechnology.10(24): 49324940. ISSN 1684-5315.

Van Steenis, C.G.G.J. 1975. Flora. Jakarta : PT Pradnya Paramitha.

Widianingsih, Mastuti. 2016. Aktivitas Antioksidan Ekstrak Metanol Buah Naga Merah (Hylocereus polyrhizus (F.A.C Weber) Britton \& Rose) Hasil Maserasi dan Dipekatkan dengan Kering Angin. Jurnal Wiyata. 3 (2).

Winarno, F.G. 2002. Kimia Pangan dan Gizi. Jakarta: PT. Gramedia.

Winarsi, H. 2007. Antioksidan Alami dan Radikal Bebas. Yogyakarta: Penerbit Kanisius. 
Wu, LC., Hsu H., Chen Y., Chiu C., Lin Y \& Ho J. 2006. Antioxidant And Antiproliferative Activites Of Red Pitaya. Food Chemistry. 95: 319-327.

Zhang, L., Lucas T., Doursat C., Flick, D \& Wagner M. 2009. Effects of crust constraints on bread expansion and CO2 release. Journal of Food Engineering. 80: 1302-1311. 